\title{
CORRELATION BETWEEN RESPIRATORY FREQUENCY (RR) AND OUTCOME IN HEAD INJURY PATIENTS IN EMERGENCY ROOM OF BANGIL HOSPITAL, PASURUAN DISTRICT
}

\author{
Ida Zuhroidah ${ }^{1}$, Ayu Dewi Nastiti ${ }^{1}$, Nurul Huda ${ }^{1}$, Novi Rahmania ${ }^{1}$ \\ ${ }^{1}$ Nursing Academy of Pasuruan Government \\ *Correspondence: \\ Ida Zuhroidah \\ Email: ida_zuh@yahoo.com
}

\begin{abstract}
Background: Head injuries are a major cause of disability and death under the age of 45 years. The main focus on handling head injury patients is to prevent and limit the occurrence of secondary brain injury which will ultimately affect the outcome of the sufferer. Emergency conditions in head injury patients certainly require quick and appropriate help for better outcome outcomes.

Objectives: The purpose of this study was to determine the relationship of respiratory frequency with the outcome of head injury patients in the emergency department of Bangil Hospital, Pasuruan District.

Method: This research method is quantitative with a cross sectional approach involving 53 respondents. The sampling technique uses purposive sampling method. The outcome of head injury patients was measured using the Trauma and Injury Severity Score (TRISS) scale.

Results: Data were analyzed using the Spearman test which showed a relationship p value $=0.013<\alpha=0.05$ so that $\mathrm{H} 0$ was rejected or there was a significant relationship between respiratory frequency (RR) and the outcome of head injury patients.

Conclusion: The need for improvement and development of nurse resources through nursing education, emergency training and evaluation of health services at the ED.
\end{abstract}

Key words: Head Injury, Respiratory Frequency (RR), Outcome.

\section{INTRODUCTION}

Head injuries are a major cause of disability and death in individuals under 45 years of age (World Health Organization [WHO], 2013). In Indonesia the incidence of traffic accidents from 2009-2013 has increased by an average of $12.29 \%$ per year. An increase in the number of accidents was followed by an increase in the number of deaths, serious injuries and minor injuries (Badan Pusat Statistik [BPS], 2013).

The main focus of managing patients who experience head injuries is primarily to prevent and limit the occurrence of secondary brain injury which will ultimately affect the outcome of patients (Letarte, 2008). One that can be used as a benchmark in determining the outcome of head injury patients is the respiratory frequency of patients (Bieler, et al., 2017).

Emergency conditions in head injury patients certainly require quick and appropriate help for better outcome outcomes. The time effectiveness of managing head injury patients by officers is important. The impact that occurs due to head injury if not treated immediately can cause brain metabolic disorders, impaired substrate transport to brain tissue and decreased blood flow to the brain resulting in brain ischemia. Golden period definitive therapeutic measures must be carried out less than 6 hours after the event, this is due to secondary brain injury and brain ischemia can occur 6 hours 
after the event (Riordan, et al., 2009). Estimates of outcome after head injury are important to determine the long-term effects after a head injury.

This study, researchers examined the relationship of respiratory frequency (RR) to the outcome of head injury patients. Determining outcomes in head injury patients is difficult, while accurate outcomes are very important.

One measure of head injury outcome can be done using the Trauma and Injury Severity Score (TRISS). TRISS can estimate the probability of survival and has been used more widely than other scoring systems and is considered quite effective because it includes anatomical, physiological, age, and mechanism of injury assessment (Zamzani, Fuadi, \& Nawawi, 2013).

The number of accidents in Pasuruan is quite high, which is 888 cases of accidents in 2016. While in 2015 there were only 813 cases. Data obtained from RSUD Bangil head injury sufferers based on medical record data from IGD RSUD Bangil specifically noted that patients with mild head injuries in the last three years were in 2014 as many as 167 cases, in 2015 as many as 182 cases while 2016 as many as 188 cases.

Based on these problems, researchers were interested in examining the relationship of respiratory frequency (RR) to the outcome of head injury patients in Bangil Hospital Pasuruan District.

\section{METHODS}

Study Design

The research design used is quantitative research with cross sectional approach.

\section{Setting}

This research was conducted in the emergency department of Bangil Hospital Pasuruan District.

\section{Research Subject}

The population in this study were all patients with head injuries in the emergency department of Bangil Hospital, Pasuruan District. The sampling technique uses purposive sampling method. The sample in this study were 53 patients with head injuries in the emergency department of Bangil Hospital, Pasuruan District.

\section{Instrument}

The instruments used were Trauma and Injury Severity Score (TRISS) scale for the outcome of head injury patients. The instrument of Respiratory Frequency used were Respiratory Rate (RR).

\section{Data Analysis}

The results of this study were analyzed using the Spearmen Rho Test with value of $\alpha=0.05$.

\section{RESULTS}

Characteristics of Respondents

Table 1. Characteristics of Respondent in Emergency Room of Bangil Hospital, Pasuruan District on April until May, $2018(n=53)$.

\begin{tabular}{|c|c|c|c|}
\hline \multicolumn{2}{|c|}{ Characteristics } & $\mathrm{N}$ & $\%$ \\
\hline \multirow{2}{*}{ Sex } & Male & 31 & 58 \\
\hline & Female & 22 & 42 \\
\hline \multirow{2}{*}{ Age } & $<55$ year-old & 49 & 92 \\
\hline & $\geq 55$ year-old & 4 & 8 \\
\hline \multirow{3}{*}{ GCS } & Low & 24 & 45 \\
\hline & Moderate & 13 & 25 \\
\hline & High & 16 & 30 \\
\hline \multirow{2}{*}{$\begin{array}{l}\text { Systolic } \\
\text { Pressure } \\
\end{array}$} & $<90 \mathrm{mmHg}$ & 7 & 13 \\
\hline & $\geq 90 \mathrm{mmHg}$ & 46 & 87 \\
\hline \multirow{2}{*}{$\begin{array}{c}\text { Respiratory } \\
\text { Rate (RR) }\end{array}$} & Normal & 50 & 94 \\
\hline & Abnormal & 3 & 6 \\
\hline \multirow{2}{*}{ Pulse } & Normal & 40 & 75 \\
\hline & Abnormal & 13 & 25 \\
\hline \multirow{2}{*}{$\begin{array}{c}\text { Trauma in other } \\
\text { organs (ISS } \\
\text { score) } \\
\end{array}$} & Major & 10 & 19 \\
\hline & Minor & 43 & 81 \\
\hline \multirow{2}{*}{$\begin{array}{c}\text { Injury } \\
\text { Mechanism }\end{array}$} & KLL & 50 & 94 \\
\hline & Non KLL & 3 & 6 \\
\hline
\end{tabular}

Sources: Primary Data

Table 1 above shows that the number of male patients with hale head injury is higher than female (31 cases or $58 \%$ ). While the majority of respondents as many as 49 patients $(92 \%)$ with head injuries aged under 55 years. There are cases that occurred related to head injury including 24 (45\%) minor head injuries, moderate head injury (13\%) and severe head injury (16\%). There are 7 patients whose systolic blood pressure was under $90 \mathrm{mmHg}$ were $(13 \%)$. The respiratory rate of the majority of respondents (50 patients or $94 \%$ ) are within the normal range. Out of 53 patients with head injury, 40 respondents $(75 \%)$ have normal pulse frequency. The trauma variable in the other 
organs of the table was obtained from a total of There are 10 patients $(19 \%)$ out of the 53 medical records of head injury experienced major trauma. A total of 50 (94\%) of respondents suffered head injuries due to traffic accidents.

Bivariate Analysis of Respiratory Frequency and Outcome in Head Injury Patients in Emergency Room of Bangil Hospital, Pasuruan District

Table 2. The Result of Bivariate Analysis of Respiratory Frequency and Outcome in Head Injury Patients in Emergency Room of Bangil Hospital, Pasuruan District $(\mathrm{n}=53)$.

\begin{tabular}{ccccc}
\hline $\begin{array}{c}\text { Variabel } \\
\text { Dependent }\end{array}$ & $\begin{array}{c}\text { Variabel } \\
\text { Independent }\end{array}$ & $\mathrm{r}$ & Rerata \pm s.b & p value \\
\hline $\begin{array}{c}\text { Outcome } \\
\text { Pasien }\end{array}$ & RR & 0,333 & $(21,64 \pm 2,94)$ & 0,013 \\
\hline \multicolumn{2}{l}{ Sources: Primary Data } & & &
\end{tabular}

Based on table 2 the results of the Spearman correlation test obtained a significance value of 0.013 indicating that the correlation between respiratory frequency and the outcome of head injury patients was significant. The Spearman correlation value of 0.338 shows that the direction of positive correlation with strength is weak.

\section{DISCUSSION}

Based on the results of the study it was found that the respiratory frequency had a significant relationship with the outcome of head injury patients. This is indicated by the $\mathrm{p}$ value $=0.013$ and the correlation coefficient $(r)$ 0.338 , which means that the respiratory frequency has a relationship with the outcome of head injury patients with weak strength.

According to Minardi \& Crocco (2009) states that the frequency of breath $<10 \mathrm{x} /$ minute is associated with a poor prognosis due to decreased oxygenation and perfusion to the brain or indicates that cerebral compression has occurred due to an increase in ICT especially the initial phase of head injury (Santosa, Rahayu, \& Balafif, 2016). The frequency of breathing less than 12 times per minute or $>24$ times per minute increases the risk of death in head injury patients (Smith \& Roberts, 2011; Yu et al., 2010 in Alligood, 2014).

According to Kulesza et al. (Salim, 2015), they stated that hypoxia and oxygen saturation lower than $90 \%$ were associated with poor results. Both the increase and decrease in RR beyond normal range are associated with poor results in head injury patients. Respiratory frequency is a good predictor of the outcome of head injury patients, along with systolic blood pressure (Melo, et al., 2010).

Several research studies have shown that a decrease in oxygen saturation and tissue perfusion takes 12-24 hours. This time is the compensation time needed by the body for complications caused such as lung injuries that have an impact on oxygen saturation and the patient's breathing frequency.

\section{CONCLUSION}

Based on the results of the study there are several things that can be concluded, among others:

1. There is a significant relationship between respiratory frequency (RR) and the outcome of head injury patients in the emergency department of Bangil Hospital, Pasuruan District.

\section{SUGGESTION}

The need for improvement and development of nurse resources through nursing education, emergency training and evaluation of health services at the ED.

\section{REFERENCES}

Alligood, M. R. (2014). Nursing theory \& their work ( 8 th ed). Toronto, Missouri: Mosby Elsevier. Inc.

Badan Pusat Statistik [BPS]. (2013). Statistik Transportasi 2013. Jakarta: Badan Statistik Indonesia.

Bieler, D., Franke, A., Lefering, R., Hentsch, S., Willms, A., Kulla, M., ... \& TraumaRegister DGU. (2017). Does the presence of an emergency physician influence pre-hospital time, pre-hospital interventions and the mortality of severely injured patients? A matched-pair analysis based on the trauma registry of the German Trauma Society (TraumaRegister DGU®). Injury, 48 (1), 32-40. doi. 10.1016/j.injury.2016.08.015.

Letarte, P. (2008). Management of Spesific Injury: The Brain. Trauma. Edisi 6. USA: McGraw Hill.

Melo, J. R. T., Rocco, F. D., Blanot, S., Oliveira-Filho, J., Roujeau, T., Sainte- 
Rose, C., ... \& Zerah, M. (2010). Mortality in children with severe head trauma: predictive factors and proposal for a new predictive scale. Neurosurgery, 67(6), 1542-1547.

Minardi, J., \& Crocco, T. J. (2009). Management of traumatic brain injury: first link in chain of survival. Mount Sinai Journal of Medicine: A Journal of Translational and Personalized Medicine: A Journal of Translational and Personalized Medicine, 76(2), 138-144.

Riordan, W.P., Norris, P.R., Jenkins, J.M., Morris, J.A. (2009). Early loss of heart rate complexity predicts mortality regardless of mechanism, anatomic location, or severity of injury in 2178 trauma patients. Journal of Surgical Research. 156(2):283-289. doi. 10.1016/j.jss.2009.03.086.

Santoso, M. I. E., Rahayu, M., \& Balafif, F. (2016). CORRELATION OF SEVERE HEAD INJURY EPIDURAL HEMATOMA TREPANATION RESPOND TIME WITH OUTCOME. Malang Neurology Journal, 2(1), 14-18.

Salim, C. (2015). Sistem Penilaian Trauma. Cermin Dunia Kedokteran 232. 42(9), $7-$ 9.

World Health Organization [WHO]. (2013). Road Traffic Injuries. Switzerland. Retrieved at October, 2013 from http://www.who.int/mediacentre/factshee stfs258en.

Zamzami, N. M., Fuadi, I., \& Nawawi, A. M. (2013). Angka Kejadian dan Outcome Cedera Otak di RS. Hasan Sadikin Bandung Tahun 2008-2010. Jurnal Neuroanastesi Indonesia, 2(2), 89-94.

Cite This Article As: Zuhroidah, I., Nastiti, A. D., Huda, N., \& Rahmania, N. Correlation Between Respiratory Frequency (RR) and Outcome in Head Injury Patients in Emergency Room of Bangil Hospital, Pasuruan District. Nurse and Health: Jurnal Keperawatan 2018; 7(2): 148-151. 